\title{
The Italian Public's Reception of the Fascist Discourse on Britain
}

\author{
Concerning Britain, I heard everywhere the harshest words, words \\ of hatred from the people who do not forget, and I heard many don- \\ nette [poor women] with little education show [anti-British] hatred- \\ fierce hatred. ${ }^{1}$
}

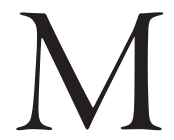

USSOLINI'S ATTEMPT TO TRANSFORM Italians was not a spectacular success. The catastrophic defeat in the war and the quick fall of the regime in 1943 demonstrated that the experiment to create a 'Fascist New Man' had failed. However, the failure to create a nation of warrior supermen does not mean that the regime did not have a long-lasting impact on Italian society, shaping the character of the Italian people in other ways. The questions of how much consensus the regime enjoyed among Italians and to what extent the Italian people had been 'Fascistised' have been the subject of lively debate among historians. While Renzo De Felice's position on the subject changed more than once, his most dominant thesis claimed that the years between 1929 and the Ethiopian War, culminating in the proclamation of the empire, were the period of greatest consensus for the regime. ${ }^{2}$ In those years, De Felice maintains, most Italians accepted the regime and Mussolini's leadership. ${ }^{3}$ Such an interpretation has been criticised by other historians including Colarizi, Bosworth and Corner, who argued not just that Fascist indoctrination was superficial but also that the support the regime enjoyed from the Italian people was already waning by the late 1930 . ${ }^{4}$ Connected to this debate is the extent to which the discourse described by this work, developed as it was by the elite of Fascist culture and politics, had been absorbed by Italian society at large.

The reception of anti-British themes by the Italian people has not been thoroughly analysed. Renzo De Felice analysed the subject in his Mussolini l'Alleato, writing that 
[anti-British propaganda] was, among the ones undertaken by Fascism, the one [that] achieved the greater results. As it is impossible to dwell in a thorough explanation of the fact, which would require the consideration of a whole series of factors, among which the preexistence, as it has been said, of an Anglophobic cultural tradition, both secular and Catholic, revived by the Ethiopian War and by the sanctions and by the petty English vexations on the Italian naval traffic in the months before the intervention, the scarce direct knowledge, on a popular level of the English and of England, country of limited Italian working immigration, the large use by [the] British side of colonial and Dominions troops, often considered of colour, or, anyway, 'barbarians,' the often counterproductive effects, which, especially in the first phase of the war had the English radio transmissions for Italy [...] we will notice how the few studies on the letters and diaries of fighting and deceased men, the most truthful memorial literature, the censorship of the correspondence show how only regarding the English the war was truly felt by large sectors, especially among the youth, and there were instances of contempt and hatred not found in the regard of other enemies.

Further research on public opinion did not produce extensive results on the subject of Britain and studies remain 'limited.' Corner argued that the regime achieved a certain degree of success in creating anti-British (and anti-French) feelings, convincing the Italian people that these nations were depriving Italy of its rightful place in the Mediterranean. ${ }^{6}$ Colarizi's work devotes greater, if passing, attention to the subject, concluding that while at the time of the Ethiopian War Fascist propaganda had managed to raise hatred against the Western powers, the regime failed to create consistent Francophobic and Anglophobic sentiment before and after the Second World War. Not much space is devoted to Britain in particular, especially in the years before 1940.7

The regime's reports on the feelings and attitudes of the Italian people are the most useful tool to test the effectiveness of the Fascist discourse concerning Britain and examining the impact of its themes.

Assessing public opinion in a dictatorship poses a number of methodological challenges. As Colarizi noted, the absence of modern polling data concerning the Fascist era meant that the 'power-society' relationship of the time must be studied through the rougher, but no less interesting, methods created and perfected by the regime itself to understand the public mood. The most important of these was the Divisione Generale di Pubblica Sicurezza (General Division of 
Public Security) and the Political Police, both of which were organs of the Ministry of Interior. ${ }^{8}$ Concerning the credibility of Fascist documentation, Colarizi maintains that 'the homogeneity of the source from which these sources were obtained' allows a reading of them as a polling system. This study is based on the assumption that these documents, together with the correspondence of civilians and soldiers, can indeed be read as a representative, if not always accurate, picture of reality at the time. It is necessary to clarify some methodological premises concerning the following analysis.

The first is the availability of sources. As mentioned above, Fascist officials were especially concerned with matters of public order, yet devoted less attention to the image of the enemy on the home front. In the context of this study, the number of Fascist sources dealing specifically with Britain is limited and, before the Ethiopian War, practically nonexistent. Finding evidence of the attitude of the Italian people towards the British becomes easier as the war drew closer, but still, the amount of evidence, especially during the tense phase between the Ethiopian War and the Spanish Civil War, is surprisingly sparse. However, the available material allows a general, if contradictory, picture of how the Italian people perceived the British adversary before and during the Second World War to be drawn.

The second difficulty concerns the analysis of personal correspondence. One example is Christopher Duggan's Fascist Voices, which features a collection of letters written by common Italians to the Duce. ' It must be remembered that the letters reaching Mussolini could have been filtered by his secretariat, and that people writing personally to Mussolini would presumably tend not to criticise the dictator nor prove sympathetic towards Britain. In this sense, the extent to which they are representative should not be exaggerated. At the same time, Mussolini's secretariat did receive (anonymous) letters criticising his choices, especially concerning foreign policy and his alignment with Germany, proving that the usefulness of the secretariat as a source should not be underestimated either. The influence of self-censorship should also be kept in mind when analysing letters sent by soldiers, such as the sources provided by Avagliano and Palmieri's works. ${ }^{10}$

Lastly, the role of the local Fascist authorities on the one hand and of the police and informers on the other also brings about difficulties. The former had an interest in depicting local public opinion in a way that would conform to the expectations of the regime and was symptomatic of effective Fascist institutions. They were also interested in reporting disturbances or lack of support for the institutions, lest being accused of having been idle should the situation prove troublesome later. ${ }^{11}$ At the same time, as Colarizi explained, the role of the 
informant has often been discredited by the prefects and Questori themselves, as informants were anonymous to them and often criticised the role of the local Fascist authorities. The reports from Sardinia, as we will see, for example, are always peculiarly pessimistic and critical.

\section{The Ethiopian War}

Britain's conduct during the Ethiopian crisis roused a massive anti-British response in Italian public opinion. As Christopher Duggan observed, the letters Mussolini received from many Italians often showed genuine anti-British feeling:

In the view of many, the opposition shown by Britain in particular to the invasion of Ethiopia was the product of fear - fear that Italy with its new spiritual energy and unified sense of mission was resurrecting the glorious military traditions of ancient Rome and would soon be able to threaten the imperial dominance of the increasingly materialistic, corrupt and effete world powers. ${ }^{12}$

These feelings were remarkably consistent with Fascist public discourse. Some of the tropes common during the Great War reemerged as well: one man from Milan complained in his diary of the ingratitude of the 'English barbarians,' who behaved as if Italy had not lost 700,000 men during the conflict 'to save the British Empire.'13 One report from Milan underlined how the British attitude during the conflict had increased support for the Ethiopian War and that 'the Milanese people are [. . . ] irked by the actions of the English government and ready to accept any event, even against England itself, while Fascist groups organised demonstrations against Britain. '14 The intensity of anti-British feeling expressed by parts of the Italian public was such that, in summer 1935, it was necessary to triple the amount of Carabinieri guarding the British embassy in Rome. ${ }^{15}$ A Fascist observer from Rome commented that many intellectuals were disgusted by British actions towards Italy: '[these intellectuals] show what a nauseating effect England's attitude has caused. An old ex-journalist in his eighties told me that he would, despite his age, go and whistle in front the English embassy!'16

Other reports hint that France was still considered with a certain benevolence, which is unsurprising considering the more cautious French attitude during the Ethiopian crisis; yet concerning Britain, reports from all over the peninsula show a growing hostility. ${ }^{17}$ At the same time, isolated individuals here and there criticised the Ethiopian enterprise, as both Duggan and Bosworth 
document. ${ }^{18}$ Of these, some opposed the war for fear of confronting Britain. ${ }^{19}$ However, as mentioned before, even historians opposed to the notion of a lasting Fascist consensus, like Corner, accept that Italian public opinion had been influenced by anti-British propaganda during that period. Simona Colarizi argued that the first reaction of the Italian public to the tensions with the allies was one of fear. While the regime had fully managed to create a feeling of hostility towards the British nation, which was 'starving' Italy, the mere nature of the propaganda - which continuously underlined how subordinate Italy was to the Western allies - gave the public the idea that the danger of opposing them was great. As soon as it became clear that the British would not follow their threats with actions, however, the public's enthusiasm skyrocketed. ${ }^{20}$

These feelings clearly appear in a letter sent by the American journalist Joseph Ravotto to his chief editor in 1937 :

Recently in Capri and Amalfi, where Fascist propaganda has not penetrated as deeply as in the big centres, I found that the hatred and intensity of the feeling $[s i c]$ which dominated during the Ethiopian conflict [...] were stronger than ever. Eden is still the devil for every Italian, him being an ardent or mild Fascist. ${ }^{21}$

Ravotto gave many examples of this Anglophobic sentiment. One example was a Capri peasant, who had fought for three years in the trenches during the Great War and who would have gladly volunteered to fight the British in the case of war: 'the English are a bunch of hypocrites [he told Ravotto,] if they emerged as victors from the last war, they owe it in great part to us.' However, the British were ungrateful, the peasant thought, and when Italy had attempted to take some of the little Britain had not taken for itself, they had tried to rouse the whole world against it. 'We will have one time to fight against the English,' he concluded, 'for they are [...] jealous of our development and fear that Mussolini could become too powerful. The sooner it happens, the better. ${ }^{.22}$ Another example was a taxi driver from Amalfi, who said he would also volunteer to fight against the English despite being 58 years old. He would even sacrifice the lives of his two sons, I 4 and I 8 years old, 'if that would contribute to humble this race that for too long has dominated the world.' He was sure, he added, that for the British the end was approaching. One Italian friend of Ravotto's was open about his contempt for Britain's military qualities. He believed that the Regia Marina, despite being smaller, could beat the Royal Navy: 'Our submarines, our cruisers, our mas: small and quick boats with only two missiles and two men, could overthrow the powerful from their throne. The English thought twice about 
[fighting Italy] for we have little to lose and we will not even lose this little. ${ }^{23}$ The notion that the British were not a martial race had permeated others, as well. Another Italian friend had written to Ravotto that

the English are not soldiers. The other Allied troops had always to help them with great difficulties with the recruitment $[s i c]$. They are forced to offer all kinds of treats to induce men to enlist. Despite this weakness of theirs, they always managed to get by, for they have fought their battles more with money than with men. ${ }^{24}$

\section{Nonbelligerence and War}

Colarizi underlined the scarce enthusiasm for war alongside Germany before the German victories in France. Already in 1938, the idea of a war against France was often unpopular and in some places, such as Trieste, the people would have preferred a war against Germany. In May 1940 Fascist informers among the citizens of Piedmont and Genoa put their hopes in a victory of the 'democratic states' against the Germans. ${ }^{25}$ Referring to the police records of people investigated for 'subversive' comments, Bosworth talked of the 'esteem of the English enemy,' referring to the period before the conflict and nonbelligerence. ${ }^{26}$ For the purposes of this study, however, it is interesting to note that while sympathy for France was (and continued to be after this point) often reported, sympathy for Britain is conspicuous in its almost complete absence. On the other hand, sympathy for the democratic states was often connected, and directly linked, to the opposition against Germany, a country that, as Colarizi abundantly documents, was truly and deeply loathed by most Italians. ${ }^{27}$ In the uncertain period before the war and during the first months of nonbelligerence, there is no evidence of widespread expressions of hostility against Britain, but there was no excess of support either. One report from Ancona, dating to 1937, revealed that rather than against the French, the hostility of the people was directed against Britain 'because of the spirit of these populations, which would not suffer any prepotence. ${ }^{28}$

A June 1939 OVRA (the Organization for the Vigilance and Repression of Anti-Fascism) report denounced the attitude of students in Milan, claiming that 'among the students, that is, the educated people, there are too many who don't think as they should.' However, this attitude was exemplified by the sympathy these students showed for France, not Britain. ${ }^{29}$ Another report about the Milanese public in September 1939 scornfully noted that the people there tended not to consider Britain as the instigator of the war, blaming Hitler instead: the 
report specified that such views were held not only by the popolino (small folk) but in 'intellectual and Fascist circles' as well. ${ }^{30}$

However, there were reports that suggested that reality was more nuanced than the idea of an Italian people overwhelmingly benevolent towards Westerners. One report, drafted in June 1939, stated that public feeling was against 'fighting for Germany, even if nobody sympathises with France. About England, people say that it is the usual egoist Albion. ${ }^{31}$ Another report drafted by the Questore of Arezzo in April 1940 mentioned how, having not been particularly engaged at first, public opinion in the province had oriented itself to thinking that Italy should not suffer the economic strangulation of the Anglo-French..$^{32}$ One from Vicenza in August claimed, echoing Mussolini's own thoughts, that it was generally believed that Britain would not dare to fight without Soviet support. ${ }^{33}$ One report from Rome concluded that the general feeling was for 'war of defence, freedom and justice,' and that for Britain the conflict was 'the war of desperation' because the growing power of the Axis certainly threatened its existence. It was the British Empire, in the hands of the Jews, which had forced the war on Italy, thankfully 'in the hands of God and Mussolini.' Henceforth, it was better to fight the war sooner rather than later, for the perfidious Albion would be better armed in the future. 'The war of poverty and spirit,' concluded the report, 'will defeat the war of wealth and arrogance. ${ }^{34} \mathrm{~A}$ report drafted on 28 August stated that the people of Rome felt the British decision to withdraw its trade fleet from the Mediterranean meant the British felt Italy was the dominant power in the region. Another report drafted on 3I August reported anti-British outbursts in the streets by the people listening to the news in public shops. A further report from the following day claimed that 'the people' opposed the British attempt to lure Italy into meaningless negotiations: 'no, Mussolini will not let the English frustrate the Italian people anymore.' The report added that anti-British feeling was growing and that it was not unusual to see common people speaking harsh words against the British. ${ }^{35}$ Hostility towards Britain appears, in these reports, sometimes connected to the idea that the British were afraid to fight, a notion echoing the perception of Britain in the military circles analysed in chapter 3:

[It is still believed] that the London Jews who warmly desire the catastrophe have a formidable foe, the Englishmen's fear; and that hence England will cave in despite the King's and Chamberlain's manifest impotence in containing the Jewish influence. ${ }^{36}$

However, after the declaration of nonbelligerence and the first developments of the conflict, hostility for Britain did not disappear. The regime itself 
investigated public opinion in order to understand how it felt about the British. One OVRA observer answered his superiors stating that the people in Carrara-Appuania Province (today Massa-Carrara) felt that the British deserved to be fought against because of their behaviour during the Ethiopian crisis and that, if war was to come, doing it immediately would be a good idea, for in the future it might prove impossible. ${ }^{37}$ Other Italians instead showed frustration for the British stubbornness in refusing Hitler's peace proposals. On 25 October 1939, a report from Milan stated that the German peace offers had been warmly received by people in the city and that the British refusal had convinced many that London did indeed want war. ${ }^{38}$ In December 1939, a report from Ascoli Piceno described the popular feeling about Britain as 'more or less unanimous,' that is, that it was the 'fomenter of discord among the peoples.' ${ }^{3}$

There was a class divide, as well. The 'bourgeoisie' (a label under which Mussolini lumped all the middle and upper-middle classes, which, he felt, did not share his goal of anthropological transformation of the Italian people) more often than others feared the war, or even hoped that Italy could reconcile with the Western democracies. ${ }^{40}$ An OVRA report stated that in Milanese commercial and industrial circles, many were still convinced of the economic and financial power of France and Britain. No mention was made, however, of their military might. ${ }^{41}$ Instead, the report underlined how these 'cowards' believed that Italy would prevail in an armed conflict, because of the 'higher war potential and training of the various arms,' and rather feared the long-term consequences of the blockade enforced by the Western powers. In this sense, the feeling of even the most sceptical mirrored the Fascist discourse and, in the case of Britain, the optimism expressed in the reports of the attachés. The world of commerce and industry had not changed this attitude by the time Italy joined the war. On 8 May 1940, another OVRA report stated that Italy should avoid war because Britain could starve the country. ${ }^{42}$

The tone of the reports is not particularly surprising since, as we have seen, the period of nonbelligerence was one in which the press adopted the most neutral approach towards Britain. Moreover, the anti-German attitude of the Italian people at the time is well known. However, already in April 1940, OVRA reported that, while Francophilia was widespread enough, 'I heard ironic comments [about] the English declarations on [their] dominion of the seas, mocking the British strength and pitying France, described as [the] victim of England. ${ }^{23}$ The change of tone in the Fascist press and the German victories in Northern Europe had an effect on the mood of the people: the image of Britain as a weak nation was reaffirmed and pro-French sentiment was expressed through 
anti-British lenses. The longing for neutrality was still strong, but antipathy for Britain was a fact that the secret police unanimously noticed. One report from Forli already in March stated that the people hated Britain more every day, and another drafted one month later shows that the trend had continued.$^{44}$ One report drafted in April said that, while most Italians wanted peace, a meaningful number of people were upset by the 'continuous prevarications' of Britain. Another report, also dating from April 1940, stated that while conscious of how the British power, for 'its perfidy,' was more dangerous than that of Germany, the people still bought the anti-Fascist arguments for neutrality. A report dated I4 May stated that the 'prevarications' against Italian trading ships had caused great indignation among the people in Milan, and that more generally 'no Italian justifies today the British behaviour.' However, they hoped that Mussolini could force the British to respect Italy without joining the war. ${ }^{45}$

By then, however, German successes in France were shifting public opinion towards war. As Philip Morgan wrote, 'it can be broadly accepted that the Italian people were behind Mussolini's decision to go to war in June 1940, on the understanding that it would be short and victorious. ${ }^{246}$ Reports hint that, by the time of the declaration of war, the Italians were overwhelmingly Anglophobic and Francophobic. As Colarizi mentioned, the sudden interventionist and anti-Allied feeling amazed even Fascist observers themselves. ${ }^{47}$ As one report from Pisa explained, 'today the entire people is Francophobic and Anglophobic. ${ }^{48}$ On I6 May an OVRA agent reported that the Milanese supported a swift settling of accounts with France and Britain before the still-unpopular Germans could win the war by themselves. ${ }^{49}$ Two days later, a report mainly focusing on the fear the Milanese had of future German hegemony on the continent stated that 'many, more than to France, [are hostile to] Britain and blame the British statesmen [who] have played with the French future, joining the war with the [British] nation unprepared and, what is worse, practically disarmed. ${ }^{50}$ On 20 May, a report claimed that the people hoped Italy would rise against France and Britain, which could not offer much resistance to Italian forces. ${ }^{51}$ As Colarizi noticed, the common perception was that the enemy was devoid of energy, with low morale and insufficient materiel. ${ }^{52}$ In Duggan's words, 'according to many informers, many people believed that the Duce had always wanted peace and blamed the outbreak of war in Europe on the arrogance and inflexibility of the British and the French. ${ }^{53}$ Even when the popular response to the declaration of war was described as cold, as in the case of a report from Aosta, it was also true that it was because 'the intellectual class, known for its Francophile attitudes, nurtured hope that war would not be declared against the neighbouring Republic. ${ }^{54}$ 
After the French defeat, we can see how the efforts of Fascist commentators to paint France and other allies of Britain as victims of London's ruthlessness were successful. If, as we have seen, antipathy for France had not matched that for Britain in 1939, in May 1940 a political police report stated that, here and there, compassion for France still emerged because France was considered the last bulwark of 'socialist democracy,' whereas nobody considered the British system truly democratic. It was easy to conclude, the report continued, that the Anglophile feelings of segments of public opinion had their root not in ideological or political reasons, like the Francophile ones, being instead the product of fear that British naval power might evoke. Once the myth of Britain's power had been broken, the 'traditional friendship' between Britain and Italy began to disappear as well. ${ }^{55}$ Britain was blamed for having sacrificed France, was accused of cowardice, and bloody revenge against it by the German Luftwaffe was 'demanded. ${ }^{56}$ Another May report from Milan stated that, if some compassion for the French could be found among public opinion, there was no exception in the general satisfaction for the doom of Britain; many were reading the anti-British poem written by the poet Monti during the Napoleonic Wars. ${ }^{57}$ One report from Aosta underlined that 'as a consequence of the sympathy towards France [after its defeat], a very much felt aversion against England has increased. ${ }^{58}$

In a particularly enlightening report from Milan dated 26 June, an OVRA agent pointed out that

now the staring eyes of the Italian people [are] directed to Britain as its number I. [sic] enemy towards which Germany and Italy will turn all their forces to crush it with no mercy. And the public opinion follows with general sympathy this decision of Italy and Germany for, if feelings of clemency for France existed, such a thing cannot be said for the hated England, and [the people] want to see it on its knees, especially after its betrayal of many little nations, lastly France. ${ }^{59}$

One report from July mentioned how a civilian observer had denounced the 'whiny' attitude so many Genoese showed for France, demanding a merciful treatment of their French 'cousins' at the peace treaties. Yet regarding Britain, 'the attitude is hostile, almost more because of its responsibility [for] the French defeat rather than for the wrongs it did to Italy. ${ }^{60}$ Even old Republicans (hardly the most ardent admirers of the regime) hated the British; a report from Forli stated that '[the British] were saying bad things about the French after having betrayed them. You hear funny things from people with this old mind-set,' commented the report. ${ }^{61}$ 
Already in May some Italians felt that the British had proven themselves to be an unwarlike people, one report from Milan stating that the people felt the British were always the first to run when confronted by the Germans. ${ }^{62} \mathrm{~A}$ few days later, after the Italian declaration of war, a report from Forlì stated that while the people in town admired the French and Belgian resistance, everyone agreed that the British had shamed themselves by running from the Germans towards the coast, not helping their allies one bit. ${ }^{63}$ It was reported on 2I June that the people from Leghorn, the working class in particular, were even more optimistic, believing that the war would be over by the end of July. ${ }^{64}$ By this stage, the feeling among the public emerging from the reports perfectly mirrored the Fascist discourse; an OVRA report from Milan stated that the common belief was that peace was near. The reason was that 'the English are used to a comfortable life and to eat well, as well as work little or do nothing' and they would soon give up before Germany could destroy and invade Britain and before Italy could disrupt its communication lines and invade its Mediterranean possessions. ${ }^{65}$ Workers from Leghorn, a report drafted on 17 June stated, mocked the Royal Navy as a bunch of 'carcasses,' wondering what such wretches could do against 'our modern and powerful fleet, suggesting that the hammering statement that the Regia Marina was by then the first force in the Mediterranean had not been in vain. ${ }^{66}$ A report from Avellino on the state of local public opinion between April and July 1940 depicted a very optimistic situation:

Already with the beginning of the hostilities [the population] had started to have the feeling that the war was not going to be that difficult for Italians, and that both [because of the great German victories] and because of the deeply rooted conviction that the Axis powers had prepared themselves [for the war] with better care; successively, after the [French surrender] and especially following the victories obtained by our [forces] in the colonies and the great battle in the Ionian [Sea], the myth of the invincibility of the English Fleet having faded, nobody doubts the final outcome anymore, and nobody fears the always threatened economic blockade. ${ }^{67}$

One report from Asti drafted on 3I July mentioned the growing resentment against Britain caused by its stubborn refusal to address the Fuhrer's 'humanitarian speech' and by the alleged mistreatment of Italian nationals in Britain. ${ }^{68}$

Many Italian soldiers embraced the Fascist view of the war as a crusade against the unjust accumulation of the world's wealth in the hands of a minority of exploiters. Many censorship reports on the soldiers' correspondence underlined that anti-British feeling was particularly high among the troops, with one stating 
that the hatred for the British was so great that many soldiers asked to be moved to Cyrenaica to fight them. ${ }^{69}$ An analysis of the sources during the summer of optimism' shows that many also shared the stereotypes about the British moral fibre, weakened by wealth and luxuries. ${ }^{70}$ The attack against the French fleet at Mers el-Kébir in Algeria (described in Italy simply as the attack at Orano) was one of the arguments Fascist propaganda insisted on most vehemently. The Italian people, as we have seen, were particularly sensitive to the allegedly ruthless British treatment of their former French allies. A few days after Mers el-Kébir, one report from Leghorn underlined local public opinions' hostility against the British:

[The news of] English piracy against the French fleet [...] has roused the bitterest indignation; the harshest words against the English government were not spared, and against the whole nation too, described as a nation of pirates. Concerning the English prime minister, I will not repeat the words addressed at him [...] Many predict that the German occupation of Britain is close $[\ldots]$ and the rage of some is such that they dream [of] the hour when the English nation and people will be vanquished. ${ }^{71}$

The censorship reported not only anti-British hatred but also confidence in an easy victory. Soldiers mocked the endless British strategic withdrawals, cheered the inevitable Fascist victory and boasted of the superiority of the Italian forces. ${ }^{72}$ Often, the civilian population shared the soldiers' hope. The people from Messina, a report dated II July 1940 stated, hated the British more every day and wanted a quick occupation of Malta to be 'a bit more free in the Mediterranean. ${ }^{173}$ Still in late September 1940, the prefect of Milan underlined that there was no doubt concerning the eventual victorious conclusion of the war. However, public opinion was disappointed because of the prospect of a long conflict. ${ }^{74}$

Indeed as we have seen, already in late summer 1940 the Fascist discourse changed its tone in order to justify the lack of action against Britain. The popular feeling was one of disappointment at the fact that the downfall of Britain, which had been considered imminent for the whole summer, had not yet materialised. ${ }^{75}$ At the same time, British resistance against the hated Germans was admired, to the point that Aldo Valori himself had to urge the Italian people not to exaggerate the qualities of the enemy (see chapter 3). The disgust for the regime's propaganda was widespread: as a report claimed in December 1940, the consistent underrating of the enemy, the belief that the British could not take the initiative and were always just about to collapse, had been followed by bad news on all fronts. As a consequence, the report continued, the morale of the 
nation, 'poisoned by stupid and criminal propaganda [...] has no more reactive power. ${ }^{76}$ As a consequence, the British-based Radio Londra was listened to by many Italians, to the point that, in February 194I, around one thousand university students in Naples organised a march 'to protest British propaganda. ${ }^{77}$

Simona Colarizi argued that British resilience had, in that period, destroyed hope of a quick victory - or even victory at all. ${ }^{78}$ As a later OVRA report explained, 'the incredible English resistance caused a light disorientation and, here and there, the doubt that the game was much harder to win than expected started to appear. ${ }^{\text {79 }}$ The British refusal to surrender was greeted with irritation, for it implied that the war would continue. In a report of this period, a gradual admission of the fact that Britain was still strong and capable of fighting can be seen, an admission that perfectly mirrors the discourse in the press and, of course, reality. ${ }^{80}$ A report dated 7 August 1940 clearly shows the mood of the people in Milan at the time. All enthusiasm for the unavoidable and quick fall of Britain, an OVRA agent wrote, was gradually weakening. 'Too much had the might of England and of its fleet been underrated and the people believed that its annihilation was a matter of days [away]' and even in 'responsible' circles everyone was certain that the war would be over by the middle of July. ${ }^{81}$

However, a new wave of enthusiasm rose with the offensives in Africa in August and September 1940. As Colarizi points out, Mussolini was deluded by the successes in Africa, inspiring his belief that he could fight a parallel war alongside Germany. ${ }^{82}$ Deluded as he was, so too were the Italian people, and not just about the possibility of having a more autonomous role from Germany. In reference to this period, a report written in December pointed out that, during the summer 'the British withdrawal from British Somaliland resurrected the morale, and the beginning of our offensive in Egypt, with its brilliant initial results, raised the tone of the public spirit.' The people had believed again that the war was about to end and they relished the notion that Italy, and not Germany, would conclude the war. ${ }^{83}$ The people of Milan were reportedly 'galvanised' by the Italian occupation of British Somaliland, believed to be one of the greatest victories of colonial history. It was also common belief that a great Italian offensive in Egypt was imminent. Nobody 'expected so much decision in fighting the war against England,' the agent noted. The Italian Air Force, people now believed, had proven itself superior to that of the British, despite the latter's lack of modern means. The British attempt to depict the retreat from Somaliland as a victory, like Dunkirk, had been widely ridiculed by the common man. The press' hammering on the morbid details of the bombings on London contributed to the general enthusiasm, too. In September, a 'wave of optimism concerning the quick and victorious end of the war' pervaded Milan, 
mainly motivated by the German raids on London. The British people, having realised that they had been led astray by their government, would either force the government to surrender or riot. At the same time, boasting of the British radio was derided ${ }^{84}$ Even the Milanese who had previously overrated British power were increasingly certain that Britain was about to fall, and the deal with which the British had exchanged some of their colonial outposts with American warships was seen as a sign of the state of prostration London was in. ${ }^{85}$ Despite some regret expressed over the suffering of British civilians, the bombings on London were 'welcomed with joy. ${ }^{86}$

In the autumn, the mood was again very low, and would remain so during the rest of the conflict; unsurprisingly, the public mood adapted to the Italian forces' fortunes in the war. The press' routine claims of the demise of the Royal Air Force (RAF) were received with boredom. ${ }^{87}$ The British offensive in North Africa further worsened the public mood, already depressed by the Greek fiasco. In general, for the first time, the masses realised 'our inferiority in front of the enemy. ${ }^{88}$ However, this sudden awareness illustrates how successful the discourse underrating the British military qualities had been in the past. An OVRA report expressed surprise at the number of people who had been taken completely aback by the mere fact that the British would take the initiative in Africa ${ }^{89}$ 'It was not true, then' one observer reported the Milanese as saying, 'that England has men who are worth nothing, who cannot nor know how to fight. ${ }^{90}$ One bitter report from Milan sums up with remarkable realism and surprisingly harsh clarity what the public discourse about Britain had been:

England has been consistently depicted as an old paralysed man barely standing on [his] infirm legs, a slap on his shoulder enough to break him down. Before the declaration of war you could hear thousands of people saying: "Malta? Gibraltar? Suez? Three days and they are ours.' Such beliefs had to be known to our leaders, and they should have, consequently, cautioned the public opinion, informing it that England was a powerful empire, vital and rich of means, even if relatively unarmed. Instead, our propaganda blew on the fire and optimism, or rather shallowness, triumphed. ${ }^{91}$

Another report stated that

public opinion is humiliated because of the fall of Bardia. I say humiliated, not crestfallen or depressed [...] it goes back to the origin of the war when the newspapers, serious, humorous and conferenzieri [literally: conference newspapers] trouble themselves to depict the English as drunkards, bad soldiers, unable to endure hardships and to fight. ${ }^{22}$ 
At this point, public opinion was becoming less optimistic. One report from Rome described the extent of this low morale, how few believed that British pressure on Cyrenaica could be stopped, and how many felt that the boasted dominance of the Regia Marina in the Mediterranean was a joke. Generally, and compatibly with public discourse, the perception in the capital was that the war was going to be long and harsh. ${ }^{93}$ However, the propaganda failure was not absolute. As we have seen, the regime tried to minimise the effect of defeat by underrating the British success, claiming that it had only been possible because of Britain's neglect of other sectors and focus against Italy. An OVRA report from Turin dated 2I December 1940 hinted that, at least in some regions, the Italian people had accepted the official explanation of the defeats:

The difficulties met in Greece, Egypt, the Mediterranean and other theatres are essentially attributed to the fact that Great Britain has focused against Italy all its available forces, coming from all sides of the world, supported by an extremely advanced armament. ${ }^{94}$

Another report, this time from the south of Italy, dated to 24 December, went further:

The initial enemy success, that in a first moment had caused some criticism [. . . against our command, is now considered, after Marshal Graziani's report to the Duce, the inevitable effect of the crushing superiority of the enemy's technical means, which overcame our troops' heroic resistance. ${ }^{95}$

This new realisation of British technological superiority (the publication of Graziani's report to Mussolini was the key moment triggering this), was never to disappear during the conflict. However, it was compatible with the regime's ethos of spirit versus matter and helped public opinion to cope with defeat; furthermore, anger against the British for their stubbornness in prolonging the war, with the sole goal of preserving their privileges, contributed to the resistance of public morale to avoiding collapse. ${ }^{96}$ Likewise, among the soldiers, the catastrophic defeat in Cyrenaica changed the perception of their now seemingly victorious enemy. During Operation Compass in winter 1940-1941, the officers complained about the inadequacy of their materials. At the same time, the humiliation at having to ask for German help was weakened by the belief, present in both Fascist discourse and among civilian public opinion, that Italy had for months been bearing the whole weight of the war. ${ }^{97}$ Still in February 1941, one report from Milan stated that 'trust in Graziani is absolutely not shaken, and expects that he will stop the English's mercenary hordes. ${ }^{98}$ The report was clearly 
exceedingly optimistic but hints at one underlining truth: the state of public opinion was not yet completely pessimistic.

Then, the German intervention in the Balkans and in North Africa gave respite to the Italian armed forces - and likewise to Italian public opinion. As one report from Milan underlined, 'the quick advance of the Italian-German troops in Cyrenaica had an enormous impression. In one week, the morale of the people rose to the highest levels, turning into real enthusiasm. ${ }^{99}$ One of the effects of the Axis victories in spring 194I, which culminated in the expulsion of British forces from continental Europe and the reoccupation of Cyrenaica, was to once again change the image of the British in Italy. 'The majority of the people,' the report from Milan stated,

are more convinced than ever that the valour of our soldiers, now protected by means at least equivalent to the English ones and craving revenge, will not stop anytime soon. It is thought that after having freed Cyrenaica the Axis forces will, after a short stop, launch themselves [in] the conquest of Egypt. Hence, the news that numerous English generals have been captured caused amazement, for it shows at what phenomenal speed the occupation happened. It is also remarked that Italian generals are rarely captured, that they always defend themselves and often fall at the head of their troops. ${ }^{100}$

The victories 'boosted morale and led to a new certainty regarding the desperate conditions facing Britain.' The same miners, who had fantasised about leaving their work place to go and fight the British, 'show [ed] real enthusiasm, [and dreamt] that in a few days we [Italians] would arrive to hit England in Egypt.' ${ }^{\prime 01}$ A report dating from April 194I stated that the public thought 'England will shortly be eliminated from South-Eastern Europe, that the [British] resistance in Egypt will be worn out, and that new developments might shortly appear, such that the conflict might be over before long. ${ }^{\text {'102 }}$ Another report stated that

the Germanic intervention in the Mediterranean [. . . ] helped dissolving worries over the outcome of the struggle [that] had [been] born in the hearts of the craven, especially after the recent behaviour of the United States [in support of] the faltering British Empire. ${ }^{103}$

Such an optimistic attitude was confirmed by another report from Vercelli, which underlined how

a great part of public opinion, in consideration of the events [that] are engulfing the British Empire, has given up the notion that the invasion of the 
British island $[$ sic $]$ is the prerequisite for the victory of the Axis. It instead believes that only in the Mediterranean and in the Atlantic is it possible to establish the premises of the island's capitulation, for the German air offensive, however formidable and lethal, has proven to be, for now, insufficient [...] In some circles [it is believed] that the new strategic situation determined by the occupation of Crete might cause the exodus of the English fleet from the Mediterranean. ${ }^{104}$

One report on the general mood of the public opinion in the peninsula (directed to Mussolini) stated that

in many circles, the impression that the conditions of England are at least serious and that its capability of resistance exclusively depends on the help it can receive from the United States is spreading. As a consequence, the comments of the public increasingly focus on [the United States]. ${ }^{105}$

The same document reported that certain circles were critical of the excessively triumphal tones with which the Italian press had treated recent victories. What does that tell us of the state of public opinion? Of course, Britain's prospects after the defeats in the Balkans and in Africa were indeed dire and having needed German help was perceived as a humiliation. ${ }^{106}$ However, there existed a trend within public opinion of being excessively dismissive of Britain's prospects of enduring, to the point that it was even portrayed as a minor player in the Mediterranean, completely eclipsed by the United States, already in spring 194I. Another report stated that if the people of Milan believed the war would continue for a long time, it was not because 'of the English resistance, that even if furious would not be able to continue for long, but rather [because of] the American intervention. ${ }^{107}$ This seems to confirm that the excessive optimism and dismissiveness of Britain that we can find in the same Fascist press, though condemned by some, had conditioned at least some Italians.

The following months were characterised by a general stasis despite violent battles in the desert. Excessive optimism diminished but reports on public opinion suggest that few doubted a final victory. In June 1941, a few days before a British offensive in North Africa and the German invasion of the Soviet Union, a report directed to the chief of police from Abruzzo described the public mood as positive: many believed that though England, supported by the United States, could still resist for a long time, final victory was certain. ${ }^{108}$ Another report on the state of public opinion in the country, drafted in November 194I and sent to Mussolini, stated the same: public opinion assumed that British resources, 
thanks to the United States' support, were still remarkable. However, it was also believed that eventual victory was certain, especially after the 'British failure in the first phase of the battle in Marmarica.' ${ }^{109}$

The German defeat at the gates of Moscow in December 194I, as well as the second British conquest of Cyrenaica, caused a new wave of pessimism, described to Mussolini in a report written in December 194I. ${ }^{110}$ The Japanese intervention, so much celebrated by the press, did not particularly help the public mood, since it was a common opinion that the British would focus their resources in the western theatre, even if that meant losing their Asian possessions. Likewise, 'it is noticed that England manages - more solito - to make the Australians, Chinese and Dutch fight for her, with the obvious advantage of maintaining, more or less unchanged, their military efficiency in Europe and Africa.' ${ }^{111}$ The notion that the British way was to have others fight in their stead, often repeated in Fascist publications, appears in other reports as well. One of these, dating from winter 1941, reported that 'England, always generous with promises, is far from effectively intervening in Russia's favour, instead, taking advantage of the mortal struggle that [Russia] fights, it finds the necessary time to increase their war production and complete its rearmament.' ${ }^{\prime 12}$ Since victory had not come after the triumphs of spring, and the British were instead often on the offensive, the Italian people had seemingly accepted the fact that their enemy was unlikely to be defeated anytime soon. One report dating from 17 December mentioned that 'the abundance of men and materials deployed by the enemy in the North African theatre brings to mind, with anguish, the hard tests that for perhaps a long time our troops will have to face. ${ }^{113}$ And yet, both in Africa and Russia, the spring of 1942 brought new successes for the Axis forces: the Wehrmacht started a new offensive penetrating deeply in southern Russia, and the German and Italian forces in North Africa did not stop the British march west but managed to drive the British out of Cyrenaica and eventually threaten Egypt itself. Colarizi argues that there was 'no enthusiasm' for the victories against the British in 1942, the common perception being that it was, by then, too late. ${ }^{114}$

An analysis of the sources suggests a more nuanced picture: while some reports did indeed suggest that 'it was too late,' and that public enthusiasm for the victories was generally more cautious than before, the successes caused another rise in the public mood, with a renewed hope in the final victory. One August 1942 report from Naples, written at the time of the lowest British fortunes in the war, mentioned the hope that 'these hits, dealt everywhere against British power, manage to weaken it and, in the end, to exhaust it,' while at the same time Indian agitation against their colonial masters was given a certain amount 
of attention. ${ }^{15}$ Another report, this time from Trieste, underlined how public opinion was mesmerised by the Axis victories and that 'while they are not enough to push the enemy down the way of defeat yet, it is, however, believed that they deeply hit the Anglo-Saxon resources and give the absolute trust in the fateful, just victory. ${ }^{116}$ A nother report from Trieste mentioned how widespread hope was that the fragile situation of Britain in North Africa and Malta could be exploited by the Axis forces to completely expel the British from the Mediterranean, while the aerial-naval victories in the Mediterranean and the consequent 'British humiliations' were welcomed with 'lively satisfaction. ${ }^{117}$ Commenting on the failed British raid on Dieppe, France, one report mentioned that the people of Bologna, while relieved by the German success, believed that Great Britain and the United States, with their great abundance of means, would surely attempt again to land on the continent. ${ }^{118}$ By September 1942 , in the Cagliari province the public knew anything Radio Londra had said, while its broadcasts 'were discussed and often commented [upon] favourably. ${ }^{{ }^{119}} \mathrm{~A}$ similar feeling was common among the soldiers in Africa: after the victories in spring-summer 1942, the morale rose again and the censorship reported a widespread belief in final victory. Some soldiers still talked of the inevitability of Fascist victory due to the spiritual weakness of the British; one stated that one British tank would be worth ten times more if led by Italians, but the scornful comments of the summer of 1940 were, overall, gone. ${ }^{120}$ However, a bitter tone of contempt against the enemy is evident in the reports of the censorship, as well as in many individual letters all through the North African campaign. The triumphant tones of the press were echoed by many letters celebrating the expected victory against the hated British enemy. ${ }^{121}$ The collapse of the propaganda effort in the following period of stalemate and then defeat was caused by the increasingly unsustainable gap between propaganda and reality. One report drafted at the end of July 1942 stated that the population of Bolzano 'deplored that our press persists in minimizing and ridiculing the attitude to war of America and England.' ${ }^{122}$ With the defeat at Egypt's El Alamein, belief in the final victory was over once and for all, and after the loss of Africa in 1943 only a 'small core of irreducible military men' still believed victory was possible. ${ }^{123}$

\section{The Question of Anti-British Hatred}

As we have seen, there was precious little sympathy for the British before Mussolini decided to join the war and, in the last months of Italy's nonbelligerence, the public mood became distinctly opposed to Britain. Did this antipathy turn into hatred during the conflict? While somehow naïve, regime-organised 
campaigns like the distribution of 'Goddamn the English' badges met with a very lukewarm reception among the people, as mentioned above, many Italians felt frustrated by Britain's stubbornness, which prolonged a war they were tired of fighting. ${ }^{124}$ The defeats inflicted by the British and the first bombings did little to improve the image of the British among the Italian people and, by winter I940, people were generally more convinced that Britain had caused the war than they had been in 1939. ${ }^{125}$ Certainly, this hatred was by no means universal and it had class connotations. Indeed, when investigating the degree to which Italians hated the British, it is also important to remember the aforementioned class divide. Colarizi commented that, during the war, the middle class was Anglophile and pro-American. ${ }^{126}$ Mussolini himself believed that the bourgeoisie considered Britain 'the ideal of any state and also of any educated individual.' ${ }^{127}$ One report from Milan stated that 'in the popular classes, perhaps more than in the wealthy ones, the feeling of the sanctity of this war grows [and it is believed that it will] give to Europe a better tomorrow with the tearing down of the British and democratic plutocracy. ${ }^{\prime 28}$ On a similar note, one report from Cagliari written in June 194I remarked how the 'bourgeois classes' did not really feel anti-British hatred. ${ }^{129}$ Another Sardinian report underlined how, in industrial and commercial circles, 'nobody hates the English.' The report hinted that the same people were even starting to doubt the Duce and were fertile ground for anti-Fascist propaganda, especially coming from Sardinian autonomists like the exile Emilio Lussu. Interestingly enough, the author of the report linked anti-Fascist tendencies like listening to Radio Londra with the, in his opinion, unnecessarily high number of educated people on the island. ${ }^{130}$ However, another report seemed to confirm that anti-British feeling was more widespread among the Sardinian lower classes:

[The workers] are calm and disciplined. They give an example of patriotism and show understanding of the political moment [...] Our men overheard (during the transmission of war bulletins) that some minors attacked with rough words the British Empire, and declared to be ready to give up their job to join the army. ${ }^{131}$

A June 194I report from Turin reached the same conclusions: unlike the 'working masses,' it was the 'intellectual bourgeois masses' that were more sceptical: they kept pouring cold water on the optimism of the workers, reminding them that the British still had fight left in them, and that it would take years to completely defeat them. These 'anti-Fascists' also believed that even an Axis victory would be a German victory, and that German imperialism was as dangerous as the Anglo-Saxon variety. ${ }^{132}$ 
Anglophobia appears, however, overwhelming in the letters coming from soldiers fighting on the Greek front, confirming that the Fascist discourse had been, in this regard, successful in influencing public opinion among the ranks. In the minds of these soldiers, the enemy was the British rather than the Greeks. ${ }^{133}$ This does not mean that the feelings were univocal. The soldiers' correspondence shows a minority of pro-British feelings, usually linked with an anti-Fascist message. In March 194I a report from the Questore of Genoa stated that, despite the recent bombing, the population generally lacked the feeling of hatred for the British that was to be logically expected. The citizens of Genoa, the report continued, believed that the British could have completely destroyed the city, had they wanted to do so, and had instead only attacked military targets. At the same time, the general feeling was that the regime's boasts of control of the Mediterranean were hollow. ${ }^{134}$ Genoa was a city of known anti-Fascist attitudes, as well as the first to begin the anti-Fascist and anti-German insurrection at the end of the war. It is also possible to find personal correspondence mocking the official propaganda's claims that Britain was behind all of Italy's evils, while one Fascist commentator mentioned in a Navy report that in Sicily 'some felt that Sicilians could not be anti-English. ${ }^{135}$ These feelings of sympathy for the British were to increase in the following phase of stalemate and then defeat in Africa and by the unbearable hatred the Italian people felt for the Germans. As an informer from Florence mentioned in a 30 August 1942 report, there was a growing sympathy for the Americans, British and even the Russians, which increased together with the hostility for the Germans. ${ }^{136}$ On the same note, one report from Sardinia stated in 1942 that the growing hostility against the regime and hatred for the Germans meant that 'large sectors of the population would not be opposed to a British invasion of the island. ${ }^{137}$

By the time of the loss of Tunisia in spring 1943, it was clear to almost everyone that the war was lost. If the traditional anti-British message was losing its effectiveness - and there is some evidence of a growth of pro-Allied sentiment during the last phases of the African campaign - another important development was due to ensure that anti-British hatred would return with a vengeance during the last months of the Fascist war: the escalation of bombing. If belief in victory was rare by that point, the regime's orders to the press about 'hatred against the barbarians' were strongly echoed by many Italians. ${ }^{138}$ One November 1942 report from Milan noticed 'the population's deep, ever-growing hatred [of] such barbarous ways to wage war, which [...] have been inaugurated by the English. ${ }^{139}$ Another report from Apulia and the province of Matera dated to the same month stated that 'the horror caused by the numerous victims among the civilian population is made more hateful by the cynical pleasure shown by the English press as well as political personalities for the results obtained with such 
inhumane acts against open cities. ${ }^{140}$ The hatred people from Sardinia and Sicily felt for the enemy, another report underlined, was exacerbated by the choice to bomb objectives of no military value. ${ }^{141}$ One report from Trapani stated that the hatred against the enemy was fierce and increasing because of the 'bestial bombings' of civilians. ${ }^{142}$ The English were also 'making a deep impression' among the common people because of their reported 'treatment of war prisoners [...] their repeated actions against hospital ships, hospital planes and hospitals. ${ }^{1143}$ The 'particular impression' made by the news of how the British mistreated the Italian prisoners was also reported in December. ${ }^{144}$

One report from Pola mentions that the people showed distress for the loss of Libya, but kept calm and disciplined, 'curs[ing] the barbarism of the Anglo-Saxons. ${ }^{145}$ The Allies' insistence on the Axis powers surrendering without conditions also had a negative impression on the Italian people. ${ }^{146} \mathrm{~A}$ revival of patriotic feeling as a consequence of the bombings arose in the souls in front of the persisting work of destruction unleashed by the enemy on the Italian cities. ${ }^{1147}$ Many reports underlined the same general feeling: 'the vicious enemy incursions against some centres of northern Italy have caused lively indignation and deep hatred against England and America. ${ }^{148}$ As usual, the reports from Sardinia were more pessimistic: one report from Cagliari mentioned that 'hatred for England has not increased in the bourgeois classes' and that 'the hatred against the English doesn't conquer the souls of the majority. ${ }^{149}$ However, a report from Foggia underlined that 'the criminal actions of the Anglo-American airmen and of the inhumane treatment inflicted [on] our prisoners intensifies the hatred against the enemy [among] all classes. ${ }^{150}$ Similarly, a report from Frosinone stated that 'the brutal incursions on inhabited centres, on women and children, has intensified the hatred against the vile aggressors. ${ }^{\text {'51 }}$

One Fascist observer who commented on the public feeling in Catanzaro could therefore conclude that

our propaganda on the barbarism of the enemy bombings and on the inhuman treatment of our war prisoners proved effective. What is told by the families and friends of those who come back from the front and captivity intensifies the feeling of hatred for the enemy ${ }^{152}$

Pietro Cavallo underlined that, by the end of the Italian war effort, the attitude of the Italian people towards the British was changing: anti-British hostility was overshadowed by the desire to see the war end. At the same time, however, the number of attacks against Britain in Italians' correspondence increased. Most Italians were tired of the war but hated the British as much as ever, if not more. 